\title{
The Enlightenment of "Red Boat Spirit" to Cultivate Contemporary College Students
}

\author{
Wang Ruohan \\ Academy of Marxism, China JiLiang University \\ Hangzhou, Zhejiang Province, 310018
}

\begin{abstract}
Red Boat Spirit" is an important part of the treasure house of human spirit which contains the great wisdom of Chinese nation. What's more, it embodies the spirit and quality of Chinese nation. It is of great significance not only to strengthen the ideological and political education of college students, but also to promote college students to establish correct values of honor and disgrace and to let them become qualified builders and reliable successors of socialism with Chinese characteristics. Starting from the cultivation of College Students' spirit, this paper expounds the connotation of the "Red Boat Spirit", and then explores how to integrate the "Red Boat Spirit" into the ideological and political education of College students, which has far-reaching significance for the establishment of College Students' outlook on life, values and world outlook.
\end{abstract}

Keywords-Red Boat Spirit; Cultivation; Ideological and Political Education; College Students

\section{INTRODUCTION}

The realization of the Chinese dream and the great rejuvenation of the Chinese nation require the people of all ethnic groups in the country to unite and fight together, and they try to exploration and continuous dedication of several generations. As the builders of socialism with Chinese characteristics for a new era, college students are the relayers of realizing the Chinese dream and great long-distance running, as well as the future and hope of China. Colleges are the important institutions for students to be shaped. They undertake the important mission and task of cultivating correct values and guiding the correct direction of life. If the educational task is clear, the college students will be wise; if the national mission is clear, the college students will be ambitious [1-3]. Nowadays college students live in the new era of reform and opening-up with superior living conditions and strong social tolerance and openness. In the new era, how to keep the most fundamental revolution spirit, cultivate college students' concept of hard struggle, to strengthen college students education, hard work and plain living the revolution makes it better to carry forward and practice spirit of the "red boat" is that we need to explore. It also explains the important responsibility and mission of the ideological and political teachers [4].

\section{THE CORE CONNOTATION OF "RED BOAT SPIRIT"}

On June 21, 2005, Comrade Xi Jinping, then secretary of the Party Committee of Zhejiang province, published a signed article in "Guangming daily", carrying forward the "Red Boat Spirit" and leading The Times. The first time put forward and systematically expounded the historical status, profound connotation and historical significance of "Red Boat Spirit". Xi Jinping comrades in the history of deep thinking and concise theoretical expression of the spirit of "Red Boat " profound connotation of scientific summed up as "pioneer epoch-making, initiative, firm and indomitable fighting spirit, ideal quickens, loyal dedication for the people" and points out that it as "the source of the Chinese revolution spirit" and "source" of the party's advanced nature of the historical status.

On Oct. 31, 2007, just one week after the closing ceremony of the 19th national congress of the communist party of China (CPC), general secretary $\mathrm{Xi}$ Jinping led the new standing committee of the political bureau on a special trip from Beijing to Shanghai and Jiaxing in Zhejiang province to pay respects to the site of the congress, south lake red boat. On December 4, promote the "Red Boat Spirit" symposium" held in Jiaxing, political bureau of the CPC central committee and secretary of the central committee Wang Huning to attend the meeting and delivered an important speech [5-6], pointed out that the "Red Boat Spirit" embodied the spirit of the founding of the communist party of China, is the source of the Chinese revolution spirit, the beginner's mind and mission of the communist party of China". Thus further enhanced the "Red Boat Spirit" in the national influence.

\section{THE NECESSITY OF CUlTIVATING CONTEMPORARY COLLEGE STUdents WITH "RED BOAT SPIRIT"}

Since the modern times, the Chinese nation has experienced tremendous suffering and sacrifices. However, the Chinese people have never yielded and constantly struggled to overcome their own destiny [7-8]. The biggest rule in the world is time. Since the reform and opening up, we have constantly summed up historical experience and persevered in hard exploration. Finally, we have achieved remarkable results, and found the right way to realize the great rejuvenation of the Chinese nation - socialism with Chinese characteristics. You'll eventually ride the wind and cleave the waves. Socialism with Chinese characteristics has entered a new era. The Chinese nation is about to make a great historic leap from standing up, getting rich to becoming stronger in a real sense [9]. The bright 
prospect of the great rejuvenation of the Chinese nation has been presented to the world.

The university students who thrive in the new era are the most creative, energetic and infinite potential new strength groups. They are not only the hope of the Chinese nation, the future of national development, but also the inheritor of Chinese culture. College students must take the initiative to assume the historical responsibility of realizing the great rejuvenation of the Chinese nation. They should actively establish confidence and determination in the great rejuvenation of the nation. In the process of taking on the responsibility and consciously accepting the training, college students will inevitably encounter thorns, rain and rain, difficulties and obstacles. While overcoming all kinds of objective difficulties, we need more subjective strength and spiritual support and consolation. "Red boat" is the correct guide in the trajectory of life. "Red boat spirit" is an irreplaceable spiritual pillar in the process of Cultivating College Students' moral quality and firm ideals and beliefs.

\section{A. Strengthening the needs of College Students' ideals and beliefs}

In presiding over the first collective study of the 18th Political Bureau of the Central Committee, General Secretary Xi Jinping pointed out that "firm ideals and beliefs and adhere to the spiritual pursuit of the Communists are always the foundation for the Communists to settle down." "Ideal belief is the spiritual calcium of the Communists. Without ideal belief and unstable ideal belief, they will be mentally calcium deficient and suffer from cartilage disease." In other words, ideals and beliefs are an indispensable spiritual food for people. College students are the pillars of the country's future. They are faced with a new historical period of new and old exchanges and rapid development of science and technology. They shoulder the mission of building a harmonious socialist society with Chinese characteristics. Today's college students lack firm ideals and beliefs to a certain extent, and their values are not perfect. The significance of carrying forward the "Red Boat Spirit" lies in helping college students to firm their ideals and beliefs, guide their struggling goals, provide the driving force for life and improve their spiritual realm.

\section{B. The need for healthy growth of College Students}

When young people are strong, the country will be strong, when young people are prosperous, the country will be prosperous; when young people are independent, the country will be independent. Contemporary college students are the future and hope of the country. The overall goal of institutions of higher learning is their healthy development. Contemporary college students are in an era of rapid social change, the trend of peace and development, the wave of new scientific and technological revolutions, especially the great practice of China's reform and opening up and socialist market economy, are causing tremendous changes in the values of college students' lives. Many college students have been influenced by the unhealthy social atmosphere, which makes hedonism prevailing and lacks the consciousness of hard struggle. They have low moral quality, fragile psychological quality, lack of social responsibility, lack of firm belief, and poor sense of unity and cooperation. Therefore, college students must not only master the curriculum knowledge but also improve their moral cultivation, establish a correct three outlooks, They must correctly understand their own development and the future of society, and always strengthen their ideals and beliefs. To contribute to social harmony and build a socialist harmonious society.

\section{Realizing the need for the great rejuvenation of the Chinese nation}

General Secretary Xi Jinping pointed out in many meetings that in order to realize the Chinese dream better and faster, it is necessary to spread the excellent spiritual culture of our country, and it must have a strong patriotism and the realization of innovative development. The state and the nation can gain a foothold in the ever-changing historical development, and because they have their own spirit and guided by the national spirit, they can be harvested under the force of courageous progress and continuous improvement.

Contemporary Chinese Communists continue to carry forward and explore the ideological value of the "Red Boat Spirit", And successfully found a path to the dream - the road of socialism with Chinese characteristics. For Communists, we must keep in mind the "Red Boat Spirit", take it as an important guiding ideology, and thoroughly implement it into practical work, enhance the value of the "Red Boat Spirit" and carry out positive development. Looking back at the growth of the party in the past 97 years, we have seen that all revolutionary spirits are actually derived from the "Red Boat Spirit", which are further developed with the "Red Boat Spirit" as the center. Therefore, in the process of realizing the "Chinese Dream", we must also pay attention to the important value of the "Red Boat Spirit" and proceed along the road of socialism with Chinese characteristics.

\section{THE WAY OF "RED BOAT SPIRIT" TO CULTIVATE CONTEMPORARY COLLEGE STUDENTS}

\section{A. The combination of "Red Boat Spirit" and ideological and Political Teaching}

The function of teaching and educating people in colleges and universities is mainly carried out through the classroom. The ideological and political theory class is a public theory class that every university will open. Its teaching effect affects the formation of the three views of college students. Undoubtedly, the method of theoretical instillation is the most important way. Theoretical instillation is not only a simple theoretical explanation, but also a variety of teaching modes, such as oral lectures, special reports, film and television films, literary readings, poems, through network platforms. Recitations and speech contests can all be the methods used in theoretical indoctrination. This can mobilize the enthusiasm and initiative of college students, which is the active participation of students. Teaching and carrying forward the "Red Boat Spirit" is not simply about history, but through vivid scene teaching, the old-fashioned theory is turned into a vivid story to enhance the vitality of the students in class. Conditional colleges and universities can open "Red Boat Spirit" related electives, at the same time equipped with 
relevant lectures, let the "Red Boat Spirit" into the classroom, into the brain, into the heart,. Let college students accurately grasp the essence of the "Red Boat Spirit" and express it through actions, thus inheriting and carrying forward the national spirit, enhancing the collective sense of honor and national pride of college students

\section{B. The combination of "Red Boat Spirit" and the second classroom}

The "red boat spirit" education can not only rely on classroom teaching, but also play the role of the second classroom. The second class mainly refers to the colorful extracurricular activities of college students. College students can enjoy their mental health through extracurricular activities and have a strong physique. Extracurricular activities also represent campus culture to a certain extent, casting the vitality and elegance of colleges and universities, and constantly improving the vitality of colleges and universities. Every successful university has a positive University spirit. The formation of university spirit is the result of long-term accumulation of campus culture and the concentrated reflection of college students' ideals, beliefs and common behaviors. Active and healthy university spirit and rich campus culture contribute to the healthy growth of college students. Afterschool activities shape the campus culture, and the campus culture influences the cultivation of college students' personality and the shaping of the three views. Campus culture has a subtle influence on students. A healthy campus culture will give students a positive force, so that students can receive spiritual baptism, sentimental cultivation, and philosophical revelation. Therefore, how to create a positive campus culture in extracurricular activities is of great significance to the cultivation of college students. Incorporating the "Red Boat Spirit" into extracurricular activities has become an important part of campus culture, it has become a spiritual guide for shaping college students' three views, which is conducive to the healthy growth of college students. Adding "Red Boat Spirit" to extracurricular activities will guide college students to form a good three-point view, which is conducive to the development of college students and the better implementation of the educational function of "Red Boat Spirit".

\section{The combination of "Red Ship Spirit" and social practice}

There are two ways to source knowledge, one is direct experience and the other is indirect experience. The direct experience is intuitive and impressive. Indirect experience is abstract and needs to be grasped by rational thinking. Most of the higher education that college students receive is indirect experience. Therefore, different students have different ability to think rationally, and the degree of knowledge acquisition is different. In addition, textbook knowledge tends to be very theoretical, and it seems a bit boring. Therefore, how to transform boring theoretical knowledge into a teaching material that is easy to understand and more acceptable to students is a challenge for teachers. Some textbook knowledge is not available in the form of on-site teaching, while the "Red Boat Spirit" education can adopt a variety of teaching modes. The spirit of the Red Boat is shaped by a characteristic place, environment, people, and customs. It is often difficult to visualize and feel the shaping of the environment in the textbook. When you are immersed in the field, observe and inspect on the ground, many things that you can't understand in the textbook are easy to show. Therefore, within the scope of university conditions, students are organized to participate in social practice, conduct research and study, and let students personally experience, interview, and investigate, such as visiting the memorial hall in Nanhu Lake of Jiaxing, organizing students to arrange and perform historical plays related to the "Red Boat Spirit" in the community, and watching documentaries related to the "Red Boat Spirit", can enable students to experience it personally. Personally practicing will make students impressed, understand deeply, and have rich insights. Personally to appreciate the beauty of the mountains and rivers of the motherland, to reach out to all aspects of society, many of the experience will make students unforgettable for life.

\section{CONCLUSION}

The "Red Boat Spirit" embodies the spirit and quality of the Chinese nation. It plays a guiding role in the development and the formation of ideals and beliefs of college students. It is also of great significance to the future development of the entire universities. Therefore, we should actively advocate the "Red Boat Spirit" education and continue to enrich ways of developing that. Furthermore, we need to provide various platforms to combine the "Red Boat Spirit" education and social practice so that students can understand that as much as possible. Moreover, we also shall guide students to develop themselves better by internalizing the "Red Boat Spirit" into their minds and externalizing it into their actions.

\section{REFERENCES}

[1] Xi Jinping. Carrying forward the "Red Boat Spirit" in the forefront of the times [N]. Guangming Daily. 2005.

[2] Seriously study and implement the spirit of Xi Jinping's important speech in Nanhu. [N]. Zhejiang Daily.2017.

[3] Excerpts from the speech of the "Red Boat Spirit" symposium [N]. People's Daily. 2017.

[4] Liu Haolin, Huang Shaoqun: Analysis of the Political and Ethical Value of "Red Boat Spirit" [J]. Journal of the Party School of the Central Committee of the Communist Party of China, 2011 (03).

[5] Zou Jianliang. Exploration and Practice of Integrating "Red Boat Spirit" into Practical Teaching of Ideological and Political Courses [J]. Ideological and Political Course Research. 2015(02).

[6] Chen Lili. The "Red Boat Spirit" and the Cultivation of Young Marxists in Colleges and Universities [J]. Ideological Education Research. 2011(05).

[7] Li An. A Probe into the Mechanism of the Cultivation of Young Marxists in the University of "Red Boat Spirit"[J].Ideological and Theoretical Education Guide. 2016(04).

[8] Mao Shuai. "Red Boat Spirit" and "Qingma Project" Construction [J]. Comparative Study of Cultural Innovation. 2018(25).

[9] Lu Cai. The Contemporary Value of "Red Boat Spirit" in the Cultivation of Campus Culture Spirit[J]. School Party Construction and Ideological Education. 2015(05). 